\title{
Developing e-business models in practice: the case of the regional online newspaper
}

\author{
Cornelia C. Krueger* \\ Faculty of Informatics, University of Koblenz-Landau, \\ Koblenz, Germany \\ E-mail: ckrueger@uni-koblenz.de \\ ${ }^{*}$ Corresponding author
}

\author{
Paula M.C. Swatman \\ University of South Australia, \\ Adelaide, South Australia \\ E-mail: paula.swatman@unisa.edu.au
}

\begin{abstract}
The dot.com and telecoms meltdown have led to claims in the popular press that e-commerce and e-business may have gone as far as they can. In practice, of course, the rationalisation of the internet-based marketplace has really only meant that sound business practices are now required for online companies, as well as for their more conventional brethren in the physical world. As companies and individuals become more accustomed to the convenience of doing business as and when they like, traditional companies in all sectors are increasingly seeking ways of internet-enabling their products and services. In this paper we look at how the formerly very conservative newspaper industry - in particular, regional newspapers - has developed online business models. A review of relevant, literature-based e-business models is followed by a series of mini case studies of online regional newspapers in Germany, France and Italy. We find that the models actually in use by regional online papers are more sophisticated and more complex than those suggested in the academic literature and we discuss the ways in which practice can contribute to theory development. While the success of these models is not yet firmly established, it appears that there is considerable potential for successful online positioning of regional newspapers.
\end{abstract}

Keywords: e-business; e-business models; online news; positioning of online news companies.

Reference to this paper should be made as follows: Krueger, C.C. and Swatman, P.M.C. (2004) 'Developing e-business models in practice: the case of the regional online newspaper', Int. J. Information Technology and Management, Vol. 3, Nos. 2/3/4, pp.157-172.

Biographical notes: Cornelia C. Krueger is a Research Assistant in the Institute of Management at the University of Koblenz-Landau. After completing her multi-faceted degree in languages, business and cultural studies ('Diplom-Kulturwirtin') at the University of Passau in 1998, she moved on to working in industry for a few years before she decided to go back to university to do her PhD. She is currently working on the SimWeb project, a project funded by the European commission. Her research focus is on internet business models and their application in the business world. Besides she is teaching marketing and internet marketing at the University of Koblenz-Landau. 
Paula M.C. Swatman is Professor of Information Systems at the University of South Australia. She has recently returned to Australia following three years in Germany where she was Professor of E-Business and Foundation Director of the Institute for Management (Faculty of Informatics) at the University of Koblenz-Landau. She has been actively involved in e-commerce/e-business since the early $1980 \mathrm{~s}$ and has taught, researched, published and consulted widely in this area since returning to academe in the late 1980 s.

\section{Introduction}

The entire newspaper publishing industry is currently undergoing a major crisis. Although subscription numbers continue to rise, a decline in advertising placements is having a dramatic effect on publishers. Advertisers are cutting their marketing budgets in response to tight economic conditions, both in terms of product and job advertisements and, since advertising is a major source of revenue for print and online newspapers, a decline in advertising volume and value has a serious impact on newspapers' profitability. As an example, the regional and local job advertising market in Germany declined by $45 \%$, the real estate advertising market by $18.4 \%$ and automotive advertisements by $10.8 \%$ between 2001 and 2002 [1].

In response to this loss of income, publishers are cutting costs wherever they can: Staff are being retrenched; fewer news agencies are being used; and synergies are being sought wherever possible throughout the organisation, across print and online editions [1]. The Rheinzeitung, a German regional newspaper with a number of local editions to cover the special interests of the Rhine valley area, which it services, has outsourced its local editorial team [1].

Although this loss of advertising revenue affects newspapers of all types and sizes, from the national dailies to the smaller regional papers, the more limited subscription pool and greater dependence on advertising revenue of the latter group makes the issue even more pressing. Will the online editions of regional newspapers disappear, or will they be re-integrated into the print editions - or do they have a chance to become real profit centres, either within the publisher's own organisation, or perhaps even on their own?

In this paper, we take a closer look at the ways in which regional newspapers can minimise their financial difficulties and, perhaps, implement successful internet business models to improve overall profitability. Building on a case study of RZ-Online and some other European regional newspapers, which have added an online extension, we will attempt to find answers to this question. Beginning with a survey of the literature on existing internet business models, we investigate the ways in which the newspapers we examine are making use of these models. Are the internet business models described in the literature used by regional newspapers? Or can we find other, perhaps more successful, business models for this industry sector by studying the models our case studies have adopted. Finally, we recommend ways in which regional newspapers can most successfully operate online. 


\section{Business models for online content}

Afuah and Tucci [2] define an internet business model as "the method by which a firm plans to make money long term using the internet". Research into appropriate e-business models has grown significantly over the past few years, with authors taking both theoretically - and empirically - based approaches to the development of definitions and taxonomies of business models suitable for the New Economy. Table 1 summarises a number of these approaches, and provides a foundation for our later discussion of business models in the context of online news provision. The sub-sections, which follow, describe these models in more detail.

Table 1 Comparison of content provider business models

\begin{tabular}{|c|c|c|c|c|}
\hline Authors & Catchword & $\begin{array}{l}\text { Critical success } \\
\text { factors }\end{array}$ & $\begin{array}{l}\text { Sources of } \\
\text { revenue }\end{array}$ & Value chain \\
\hline Bartussek [3] & Newsfilter & $\begin{array}{l}\text { Identify and serve } \\
\text { customers' needs } \\
\text { Traditional strengths } \\
\text { New income resources }\end{array}$ & $\begin{array}{l}\text { Selling product } \\
\text { Advertising }\end{array}$ & $\begin{array}{l}\text { Producer and } \\
\text { Intermediary }\end{array}$ \\
\hline $\begin{array}{l}\text { Farhoomand/ } \\
\text { Lovelock [4] }\end{array}$ & $\begin{array}{l}\text { Content } \\
\text { provider }\end{array}$ & & Subscription fees & Intermediary \\
\hline Niewiarra [5] & $\begin{array}{l}\text { Content } \\
\text { Network }\end{array}$ & Networks & Revenue sharing & Network \\
\hline Rayport [6] & $\begin{array}{l}\text { Content } \\
\text { Business }\end{array}$ & $\begin{array}{l}\text { Revenue sharing } \\
\text { between content } \\
\text { provider and online } \\
\text { service }\end{array}$ & Revenue sharing & Network \\
\hline Weill/Vitale [7] & $\begin{array}{l}\text { Content } \\
\text { Provider }\end{array}$ & $\begin{array}{l}\text { Branding } \\
\text { Recognised as best in } \\
\text { class } \\
\text { Network }\end{array}$ & $\begin{array}{l}\text { Fees from third } \\
\text { parties or allies }\end{array}$ & Producer \\
\hline Wirtz [8] & E-information & Differentiation & $\begin{array}{l}\text { Pay per } \\
\text { transaction } \\
\text { Subscription }\end{array}$ & Intermediary \\
\hline
\end{tabular}

\section{1 e-business models for digital content}

\subsubsection{Newsfilter [3]}

Bartussek argues that newspapers need to recognise and extend their core competency as a news filter in the digital world and use this to provide a competitive advantage:

- Newspapers should conform to customers' wants and needs - only those publishers who identify and serve customers' wants will be successful.

- Newspapers should build on their traditional strengths to succeed online: 
- Content. The keyword is 'glocalisation' - a combination of regional news and international news in real time is, he believes, easy to achieve via the internet. Bartussek sees two success factors for internet-based news presentation - a dense local network of correspondents, and global information resources.

- Credibility. It is especially important to create credibility on the internet.

- Interface. Reading newspapers is a habit and readers are used to their preferred newspaper's format(s). The creation of an appropriate interface on the internet, as in all other end-devices, is another major success factor for online news presentation.

- Mobility. Paper-based newspapers are mobile, but online papers are not. Online papers can only compete with such traditional mobility by adding an $\mathrm{m}$-commerce interface. Content providers, of course, need to find telecommunications industry partners to be able to offer mobile content.

- Brand and communities. One of the bases for success in the digital world is an established and well-known brand and a clearly defined community of consumers. But it is very important to transfer the brand into the web.

- Newspapers should open up new income resources. A newspaper has two possible income resources - selling the product (subscriptions) and selling advertising. It is not yet possible to transfer subscription models to the internet because free offers are still dominating the landscape. Bartussek points out that offers have to be paid for. Therefore content must be exclusive and generate added value.

\subsubsection{Content provider [4]}

These authors describe a business-to-consumer (B2C) e-commerce business model, which they call 'content provider' - a "web-based data host and electronic publisher of newspapers and magazines" [4]. Web-based data hosts gather a variety of information and organise them into electronic databases, with revenue coming from subscription fees. Online newspapers and magazines seldom charge for general content, but rather change small fees for archived news and special services.

\subsubsection{Content network [5]}

According to Niewiarra, networks are the keys to success in content distribution. Content is used cross- and multi-media, with the increasing fragmentation of the market demanding new preparation and new ways of offering content to the customer. Multimedia distribution is one of the big challenges for traditional media companies. To manage it, companies must transmit data digitally over a variety of channels, with content adapted to the needs of the appropriate channel.

Telecommunications companies lacking sufficient content for their broadband offerings have the choice of either developing content themselves or buying it from content providers. Although content providers cannot build a successful business model without the network operators and vice versa, defining such contracts is no easy task. Even a company such as AOL Time Warner, which combines content creation with electronic distribution channels using vertical integration, must still define offers which 
are appealing to their increasingly sophisticated customers. Value-added services calibrated to the market and the target group are a necessity.

The content provider must be aware of both the kind of content it owns - whether it is positioning itself as the actual producer of content, as a content deliverer, or as a full-service content provider - and of its preferred network arrangements, e.g. telecommunications companies, ISPs, portals, or company websites.

The brand is a critical criterion for a content provider, since brand strategy influences turnover and profit significantly, not only creating a particular tradition and quality in the customer's mind but also acting as an element of recognition and binding. Personalised information will play an important role in the future, implying a new sort of product manager, who is both producing content and is also aware of the need for responsibility and ethical standards.

Niewiarra describes two business models for networks:

- Cooperation of content provider and network operator without intermediary.

Here the content provider offers both its own and acquired/purchased content under its own brand. It purchases broadband delivery capacity from a network operator and sells this to its customers. The network operator has access to the end consumer and the appropriate billing systems. The customer uses the services and pays for the broadband capacity used. S/he pays the content provider who is using the network operator's billing system.

- Cooperation of content provider and network operator with intermediary.

The content provider delivers content under its own brand. The intermediary adds value to the content and delivers the distribution technology. The network operator has access to the end consumer and the appropriate billing systems. The customer uses the services and pays for them, for example via a mobile phone provider.

\subsubsection{Content business [6]}

Rayport calls his model 'content business'. He believes that the period in which everything on the internet was free is now over. Users are increasingly accustomed to paying for internet access and this revenue should be shared between the content provider and the online service provider (previously, the way in which such revenue was shared had to be negotiated). Rayport cites the example of financial advice offered over Viacom's MTV. This model, however, has had no chance to survive, because too many providers are offering content for free.

\subsubsection{Content provider [7]}

These are firms which create and provide content in digital form to customers via third parties. The physical world analogy of a content provider is a journalist, recording artist, or stock analyst. Typical offerings include software, electronic travel guides, digital music and video. A content provider offers expertise and leadership in a niche market and it is clearly important that such a provider understands customers' needs and wants, so that $\mathrm{s} /$ he can create and price content appropriately. 
Content providers' income is fees from third parties or allies. Their technological infrastructure needs to be of a very high standard and must be able to cope with a variety of formats to cater for their many suppliers and customers. Truly successful content providers have well-known brands, since they are offering information and digital products integrated into a third party's offerings - and, indeed, are actually attracting customers to the third party's site.

\subsubsection{E-information [8]}

Wirtz defines a content business model that consists of collecting, selecting, systematising, packaging and providing content on a company-owned platform [8]. The user must have ready access to the content required, which may (or may not) be personalised. The e-information business model depends on the content offered, for example, e-politics, e-economics, which are focused on political, economic or social content. There are different ways of differentiating content - greater information depth can be achieved by specialisation in a certain category, but also by general information with a high coverage. Specialised (niche) internet offerings are more successful in generating revenues, irrespective of whether the customer is paying per transaction or subscribing. Suppliers of broader information, by contrast, can acquire more indirect advertising revenues.

\subsection{Strategic success factors for digital content}

These six authors (or groups of authors) identify a number of related factors as being crucial to success in the brave new world of digital content provision (particularly online news provision). All authors discuss the creation of digital content, with Weill and Vitale focussing almost exclusively on the role of the content creator. Branding is seen as a major issue for creating customer awareness and maintaining loyalty and visibility. Almost all authors note the importance of intermediaries as a potentially important link in the digital supply chain and Niewiarra and Rayport pay particular attention to the creation of networks, identifying the need for a multi-channel approach and for the need to create value-added services targeting specific markets and groups. Wirtz' concept of 'e-information' adds to Niewiarra's discussion of the likely creation of personalised services and products, highlighting the importance of niche markets in this sector for all consumer groups.

These authors are, of course, discussing the issue of digital content generically, rather than focusing on the role of online newspapers specifically. As part of our work within the SimWeb European Commission research project we spent almost a year talking to a variety of stakeholders within the European online news industry and it began to seem that many of the news providing organisations had identified opportunities that were not suggested by the available literature on the subject. In this paper, therefore, we investigate the activities of one small sub-group within the online news sector - regional newspapers having an online subsidiary - to see whether practice has overtaken theory and, if so, what enhancements to existing theory can be learned from the practitioners in this field. 


\section{Research approach}

The depth of the crisis facing the newspaper sector might seem to suggest that it is impossible for (particularly) regional newspapers to be successful on the internet. We therefore identified the following research questions to guide our analysis:

- $\quad$ are the internet business models described above used by regional newspapers, or are these companies implementing some other business model(s)?

- $\quad$ are the internet business models of regional newspaper realistic and successful?

While our data gathering has thus far been concentrated on the German experience, we also wanted to discover how the situation in France and Italy compares with that in Germany. We have primarily made use of 'secondary data research' $[9,10]$ for this preliminary analysis, which involves the synthesis of existing data collected for other purposes than the research project concerned; and with drawing inferences from those data. We were, however, fortunate in being able to speak at length with the CEO of a very innovative German regional newspaper, RZ-Online, and the results of these interviews have added considerably greater depth to the paper than would have been possible from secondary data alone.

We initially analysed three separate online German regional newspapers - RZ-Online (www.rz-online.de), SWOL (www.swol.de) and RON Online (www.ron.de). These are online presentations of the existing regional print newspapers Rheinzeitung, Schwäbischer Bote and Rheinpfalz. First, we analysed their websites and, as mentioned above, in the case of the RZ-Online we also talked to the CEO of the company to obtain more detailed information. These analyses provided us with a fair understanding of the German regional newspaper experience.

We then looked at three French and three Italian regional newspapers to provide a comparison of experiences in the three largest mainland European countries. Our French examples were drawn from Sudouest (www.sudouest.com), La Dépèche (www.ladepeche.com) and Le Parisien (www.leparisien.fr); while our Italian cases included Il Giornale de Vicenza (www.ilgiornaledivicenza.it), the Alto Adige Trentino (www.altoadige.quotidianiespresso.it) and the Gazzetta di Modena (www.gazzettadimodena.quotidianiespresso.it). Our primary focus in this preliminary work has been on the German regional newspaper sector, with the French and Italian cases being used as cross-cultural comparisons. The findings, which suggest that Germany is very much ahead of the other two countries in this area, made it imperative that further, in-depth investigation should take place - and this work is currently underway as part of the second stage of the SimWeb sector analysis.

\section{Findings from the cases}

There are basically five potential revenue streams for online news providers when selling to individual consumers, which apply particularly to regional online news companies: 
- $\quad$ increased consumer income:

- increasing subscriptions to the service (this is the traditional consumer-based income source for news providers)

- 'pay per view' - persuading consumers to pay to see individual information/ news items

- merchandise sales of various sorts

- increased advertising revenue:

- $\quad$ persuading more companies to place advertisements in the offline version of the news/information provider's service, which is then also available online (this is the traditional advertising-based income source for news providers)

- banner ads in the online version of the service, leading to a percentage of sales generated from the advertisements.

Business models in this sector are therefore based upon ways of increasing these revenue streams. The other major factor to take into account in identifying and extending business models is the locus of concern of the newspaper. As is clear from Figure 1, the broader the geographic focus of any newspaper's news coverage, the lesser attractive it becomes for direct marketing. Major national dailies such as The Times, Frankfurter Allgemeine Zeitung or Le Figaro (and, to an even greater extent, papers with an international locus of interest, such as the International Herald-Tribune) do not attract advertisements from supermarkets on daily specials. Their advertisers tend to be either global enterprises such as airlines or banks, or 'theme' advertising from major corporations wishing to raise their profile.

Figure 1 Advertising attractiveness depends on core competence

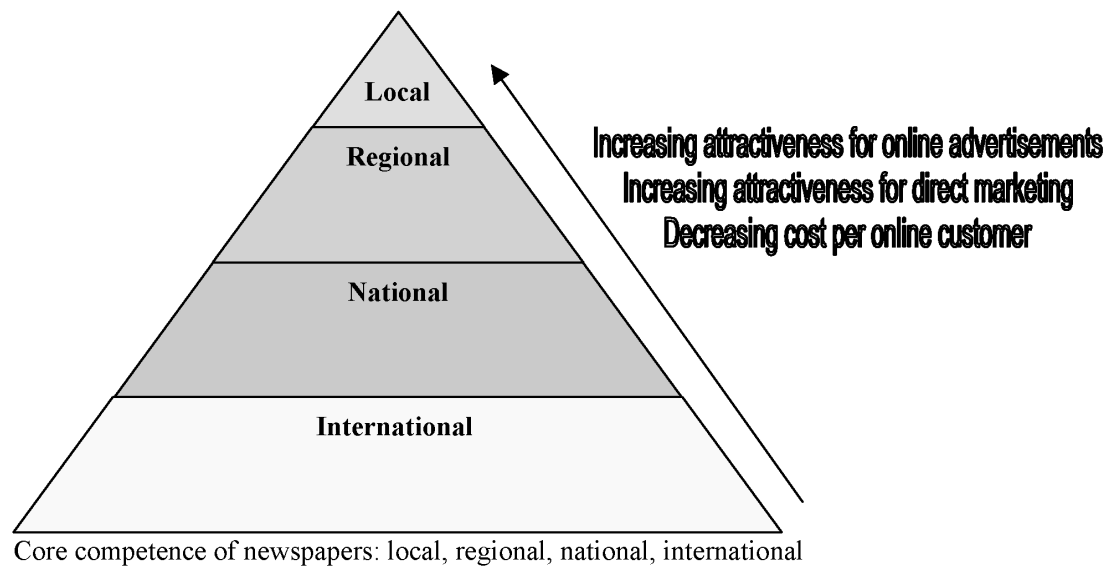

Focusing on local and regional topics has another advantage, because there are many more regionally-based than international companies (particularly SMEs). Global corporations have little interest in regional websites, because their advertising spend is primarily directed towards websites with a global reach. Although each individual regional SME spends comparatively little money on web-based advertising, where there are many such firms involved, the total spend can be significant. 
Since the newspapers with which we are concerned in this paper are regional, with a locus of concern based upon a comparatively small and clearly identified geographic area, direct marketing is an important factor in their appeal to advertisers and, consequently, in their strategic thinking.

\subsection{German regional newspapers online}

All three of the companies discussed below (RZ-Online, SWOL and RON) are based in the German state of Rhineland-Palatinate and their territories have some minor overlap. Interestingly, all three have taken clearly different approaches to building a sustainable online customer and advertiser base.

\subsubsection{RZ-Online}

RZ-Online is the online brand of the regional newspaper Rheinzeitung and offers both a 'standard' online version of the news plus a very innovative approach - a facsimile version of the print edition (the 'e-paper'), the first newspaper in the world to do so. This facsimilar version remains unique, despite the later emergence of other facsimile competitors such as the NewsStand-intermediated papers, because it is html-based and thus available from any computer linked to the internet, whereas NewsStand makes use of a proprietary version of Acrobat to deliver its information and the files can be read only via a single, specified IP-address.

In terms of direct consumer approach, RZ-Online uses its web presentation to increase subscriptions to the offline 'physical' newspaper Rheinzeitung. But beyond this fairly conventional aim, the company is offering a unique approach to providing its online information. The e-paper looks exactly like the print version and was originally free to subscribers although, from the start of 2002, RZ-Online started charging $€ 2$ a month for the product. At the moment there are 2500 subscribers to the e-paper, compared with 200,000 subscribers to the print version. To provide a feeling for how large or small a number this is, FT.com has 17,000 online subscribers and the online WSJ has 674,000 [11].

Readers cannot subscribe solely to the e-paper but must subscribe to the print version in order to get access to the online subscription. This is because the Infonline service (www.infonline.de), which is intended to provide an independent measurement of websites, only began to count website visits and page impressions from 1 September 2002 [12]. At the moment, RZ-Online is waiting for the advertising market to recover so that the paper can use this information to sell online advertising at a price, which depends on the number of visits and page impressions they obtain. Such independent measuring is quite new and thus a very important argument in selling advertisement was missing.

At present, RZ-Online is focusing on the internet-based car market, which appears very promising in Germany and is creating a car portal online profiting from its own brand and from its local and regional reach.

The core competence of RZ-Online is local and regional news and the major target groups are people living in and around the Koblenz region, plus those who originated in this part of the world but are currently living either in other parts of Germany or, even more importantly for the e-paper, abroad. Analysis of the reading habits of e-paper subscribers confirms the wisdom of a focus on core competence, identifying that local 
subscribers start reading their papers at home in the morning, then continue with the sections they did not have time to finish once they get to work. Remote subscribers tend to go first to the sports news (which, naturally, focuses on regional sporting events such as the local football league) and then to the regional news.

In addition to satisfying the demand for local news and events as a step towards increasing subscriber numbers, the company is also focusing on its advertising revenues and taking a number of innovative approaches to tying advertisers to the e-paper channel:

- RZ-Online is offering, via a subsidiary, an ISP and ASP service to local businesses. Customers of these services not only obtain RZ-Online internet access on very good terms, but obtain their own domain, their own homepage and even their own database - all of which can lead to the creation of a customer base of satisfied advertising customers for the e-paper. Every local shop with a homepage is a potential advertiser in both the print and facsimile editions.

- RZ-Online goes further - offering 'click-through' advertisements in the e-paper, which will provide genuine (and unique) added value for advertisers.

The potential strategic benefits from this combination of approaches include the possibility of charging for ISP/ASP services via commission. Merchants would then only have to share their revenue with RZ-Online when an e-paper reader clicks through the advertisement to a local web shop and actually makes a purchase. RZ-Online can also use its marketing knowledge of the e-paper readers to customise its internet presentation. News and advertisements could be placed according to the individual e-paper reader's preferences.

Sales of marketing information could form another potential revenue source - but RZ-Online does not believe that this approach fits with the company's image of a reliable and trustworthy news provider.

\subsubsection{SWOL}

SWOL is also targeting both subscriber and advertiser numbers - but in a rather different way from RZ-Online. Although both companies have created ISP subsidiaries, SWOL is concentrating its efforts on creating a series of niche markets rather than offering a unique interface and click-through advertisements.

There are a number of 'classic' advertising markets within any newspaper: job ads, car ads, real estate ads, etc. The internet provides new possibilities for developing services around these advertising markets. Services such as financial intermediation, house-seeking assistance, or online job-finding assistance are already being developed by a number of media organisations - and some of these services are proving extremely popular. The traditional advertisement in the print version is being developed into an integrated service on the internet. This is the case for SWOL.

Like RZ-Online, SWOL's core competence is local and regional news and they are trying to increase subscriptions to their print edition over the internet. But local and regional news only appears to be a vehicle enabling SWOL to lead the online reader to its local and regional information - as the fact that the company only makes a standard online presentation of their news content available for free shows. SWOL wants to be 'the' online portal for the region and attract local and regional companies to put their online advertising on the websites related to SWOL. 
As Figure 2 illustrates, the information itself is delivered by five companies (sw-ecommerce), cities (sw-cityinfo), organisations (sw-veranstaltungen), individuals (sw-singles) and clubs (sw-vereine). Revenues are gained from the more attractive advertising space:

Figure 2 The SW-network

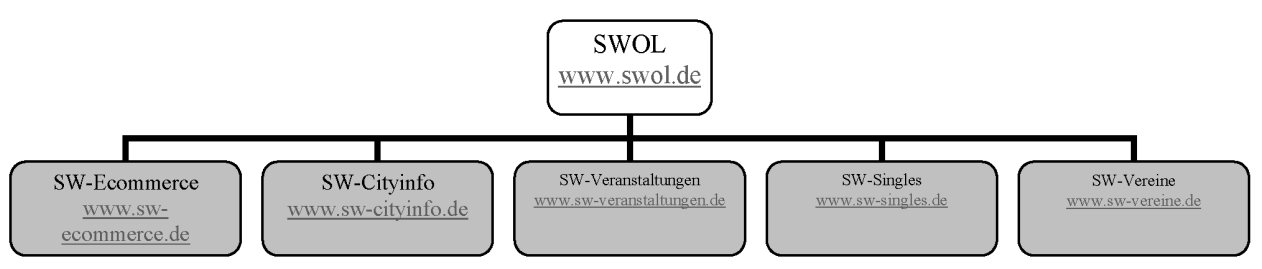

- the websites are full of interesting information for someone living in this particular region

- local or regional companies can reach their local or regional target group

- $\quad$ SWOL is a reliable brand

- from the ISP and ASP services, which are offered by DIG (Digital Information Group), a subsidiary which offers internet access and application services such as domains and homepages in variations matching the customers' (company, city, club, individual) needs and wants.

SWOL emphasises its local and regional core competence to appear more attractive to advertising customers - the strategy here is clearly niche marketing. The more local its websites are, the more likely it is that companies can reach their target group by means of a banner ad - leading the company to buy yet more advertising space. SWOL's strategy is the same as that of RZ-Online, but the approach is subtly different - rather than providing the perfect advertising environment, SWOL is trying to lure advertisers into a series of niche markets where they will feel that they can target exactly the customers they want.

\subsubsection{RON Online}

RON Online takes a different approach again - targeting individual cities across the Rhineland-Palatinate region. The homepage starts with the selection of a city and the news RON Online provides builds on this selection.

The regional specialisation applies across the whole internet presentation. Figure 3 shows the main structure of the RON Online website, showing its dual focus. On the one hand, RON Online is focusing on edited local news with hyperlinks to nearly every city in the Palatine region. On the other hand, it has established its own network 'RON Net' through which it gathers and offers information about a variety of topics, from real estate (Immo-RON) to events. 
Figure 3 RON Online network

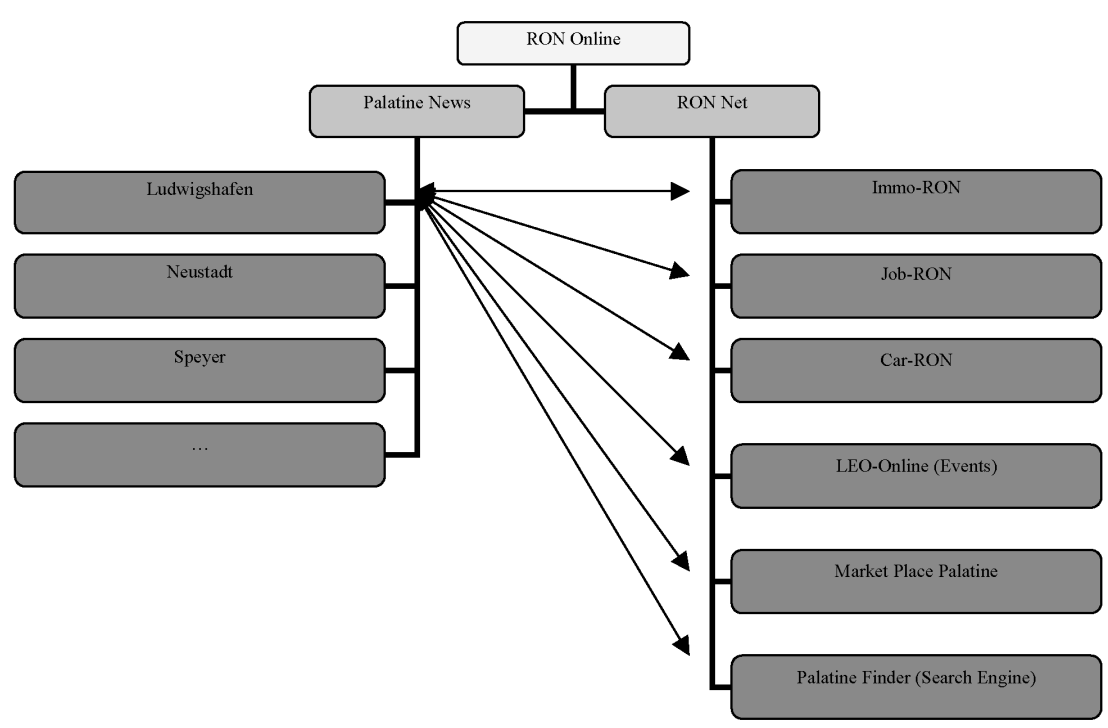

Like SWOL, RON Online wants to convince regional companies to spend their online advertising budget on www.ron.de. But the company does not only depend on advertising revenues, having taken a number of customer-focused revenue-raising measures:

- $\quad$ RON Online now charges for their archive material. The customer can choose between a free sample of the seven last days, a pay-per-view basis ( $€ 1.50$ per paper, or a full subscription for $€ 68.44$ a month).

- In addition, RON Online is, in B2C a variation of RZ-Online's B2B ISP/ASP approach, offering homepages and internet access for subscribers to the print version.

RON Online thus has a combination of income sources: advertisement, archive and internet application services. Its core competencies are local and regional news and information.

\subsection{Comparison of internet business models in theory and practice}

Comparing the business models we have identified in the literature with our three online regional German newspapers, it is interesting to see that these successful regional newspapers have not only taken three quite different approaches to increasing their subscriber and advertiser revenues, but have created remarkably sophisticated business models to achieve these ends. In fact, it is obvious that only a combination of the individual recommendations from theory can be successful in the 'real' world.

A regional online newspaper is simultaneously a producer and an intermediary - which is situated in a network. 
- $\quad$ First, German regional newspapers are still producers of news (mainly of regional news which is their core competency).

- Second, they are also intermediaries for international, national, business and financial news, which they purchase from news agencies, or from other newspapers and magazines. All three of our cases buy in the bulk (or even the entirety) of their national and international headline/political news, much if not all of their financial news, and most of their national and international sporting news. Breaking news is primarily restricted to their regional core competency. They also add value to the content they buy to adapt it to the demands of their own readers. Some of our cases have also engaged in interesting outsourcing arrangements to cut costs (Rheinzeitung, the mother company of RZ-Online, for example, has spun off its editorial group as an independent company).

- Third, the regional newspapers in Germany are creating regional networks. This is obvious with all three of the newspapers we have analysed. RZ-Online is building a network via a subsidiary to sell internet access and homepages. SWOL, while offering ISP services, is focusing on topic-centred websites. RON Online has created a regional marketplace.

For a regional newspaper it is very important to work together with an online service or application provider. RZ-Online and SWOL even have subsidiaries working in that sector. The synergy developed by this cooperation is very useful to the online business of regional newspapers. Not only can revenue be shared, but also, more the number of regional companies hosting their websites with the cooperating online service, the greater are the number of potential online advertising customers.

It is also important to have several sources of income to avoid dependence on a single revenue source. For example, online subscription + archive pay-per-view + internet access. At the content level, the newspaper has to be the number one in its region in order to attract sufficient numbers of people to its website and generate page impressions. The newspaper should concentrate on its regional core competencies online.

Research into the area of online business models, while extensive, tends to be somewhat generic in nature. Many of the authors working in this field are endeavouring to create models that can be used by companies working in widely disparate fields and across many industry sectors. Even those that concentrate on an area such as digital content provision (as in the case of the six authors we discussed earlier in this paper) are looking at the whole field of content provision - which includes not only online news, but also online music, software and even service products such as financial instruments. It is thus not surprising that the authors' recommendations tend to be reactive rather than proactive, and to reflect a fairly meta-level approach.

What we have found in our investigation of these three surprisingly innovative regional newspapers is that organisations that are aware of the specific needs of their market place can often run ahead of theory in developing strategy. Each of our examples has taken a complex, hybrid, but nonetheless unique approach to maximising revenue, using a variety of approaches: 
- RZ-Online has targeted its subscriber market via differentiation [8] and a unique and world-leading interface [3,7] - even FT.com, arguably the most successful online newspaper in the world, seeks the advice of RZ-Online's CEO! The company's approach to its B2B advertising marketplace combines branding [7] with new income sources [3] and the creation of a network [5-7] and a clever attempt to make 'happy captives' of their advertisers via value-added services and products.

- SWOL takes a niche-market approach to its subscribers $[5,8]$ and also offers value-added, high-quality services to its advertisers [5-7].

- RON Online has a heavy focus on its subscriber revenue, with a niche-focused approach, which is similar in its overall goals to that of SWOL, although using a rather different implementation perspective, but also identifies new subscriber/casual reader revenue sources [3].

All three companies are not only using a combination of the approaches suggested in the literature, but are combining them in innovative and creative ways - and showing a willingness to learn from their subscribers and advertisers which is not mentioned in the theoretical literature. But before we sum up our views on the enhancements which practice has to offer theory in this area, let us take a quick trip to France and Italy, to see what the regional newspapers online in those countries can contribute to the discussion.

\subsection{Comparison between the German, French and Italian experiences}

The situation of the French and Italian regional newspapers is rather different from that of their German colleagues. Of the six regional newspapers we analysed, not even one was selling content on its homepage.

Le Parisien, La Dépèche, Sud-Ouest in France and L'Alto Adige, La Gazzetta di Modena and Il Giornale di Vicenza in Italy were certainly targeting the same two revenue groups as the three German papers - all of them were using their internet presentation to acquire more subscribers for their print version and all were financing their online versions by online advertising by either banner ads or job, car and real estate ads. But there their activities ended. To our surprise, it appeared that they had simply transferred their print-based business model to the web without any attempt at modification.

In France, all three regional newspapers online are focusing on their regional core competence, for example, the Sud-Ouest structures its website according to the local editions (e.g. Charente, Dordogne or Loi et Garonne). Services such as 'météo' or 'circulation' are regional. Apart from Le Parisien, which is selling physical products in a section called 'galérie marchande', none of the regional newspapers is selling content or products, or has an allied internet provider. They all rely on advertising income.

In Italy, all three regional newspapers have a facsimile version of the front page of their print edition online. In other respects they are standard websites. The regional focus ranges from not very strong in the Giornale di Vicenza to very strong in the Gazzetta di Modena. The Giornale di Modena is more a collection of regional, national and international links, whereas the Gazzetta di Modena has a regional focus in nearly all its sections (e.g. 'provincia', 'società' and 'rubriche' - and even a local focus on Modena). L'Alto Adige seems to be the only one to cooperate with an internet provider which is 'kataWeb.it'. They are offering homepages, internet access and SMS together. 
In France and Italy, the regional newspapers have not yet begun using the internet to sell content, but are still offering it for free, although it is clear that the homepages are portals. They are standard websites with the content of the print edition enhanced by internal or external links. This is more obvious in Italy than in France, where the website does not yet appear to be doing more than generating advertising revenue.

\section{Conclusions}

The three regional online newspapers in Germany have a similar strategy. They are all part of a network and they all are creating a regional community for their users. Several income sources are one of the most important aspects in making money on the web. Although news content is sold, real products (e-commerce), internet access and homepages, and internet solutions such as databases (RZ-Online) are important factors in increasing the attractiveness of the online version of the newspaper. And increasing online advertising revenue is the overall goal - either by broadening the customer base (bringing regional shops online), or by increasing page impressions through niche marketing. This strategy seems a promising way to do business on the internet for regional newspapers in Germany.

In France and Italy the regional online newspapers analysed have transferred their traditional business model to the internet almost without change. Income sources include selling the print edition and online advertising. The regional newspapers have not yet developed a specific internet strategy. There are some possible explanations for this, although these should be treated with caution:

- The percentage of people using the internet is smaller in France $(22 \%)$ and Italy (34\%) than in Germany (48\%) (mediaresearch.orf.at, 2002).

- It is less common to read a regional newspaper in France and Italy than in Germany. The number of daily newspapers per 1000 inhabitants is very high in Germany (375), compared to France with 190 and Italy with 121 (www.bdzv.de). In Italy (it.yahoo.com) there are 97 regional online newspapers and in France 104 (fr.yahoo.com), while in Germany there are about 178 regional newspapers online (de.yahoo.com).

Our cultural comparison, then, did not really extend the attempt to enhance theory through practice - while the Italian regional newspapers we investigated did seem to be making a tentative start towards developing their own unique e-business model, the French papers could still be said to be in the starting blocks. Nonetheless, the three German examples showed that researchers working in the area of e-business model development might do well to seek out best practice cases on which to base their models. There is some danger in basing research in this area only on the large, well-known cases, which do not have universal applicability and which may well no longer be at the leading edge of what is possible.

While we do not in any way argue with the idea of providing generic, multi-purpose research into e-business model development criteria, we suggest that industry-sector and nationally focused research approaches also have much to offer the researcher in this field. Our work within the SimWeb project has enabled us to investigate both the online news and online music sectors across Europe from the perspective of all the major 
stakeholders - both at a broader and more superficial level via survey and, over the next 12 months, in a more detailed way by means of face-to-face interviews. This work has led to the insights contained in the present paper and, while the regional newspaper sector might seem to be a very specific one indeed, our findings offer assistance to all researchers in the area of e-business model development.

The three German newspapers we have surveyed are all investigating and experimenting with a variety of innovative and potentially profitable approaches to the creation and maintenance of e-business models - many of which are more complex and more sophisticated than those recommended in the academic literature. Whether these models will provide long-term revenue gains remains to be seen, but, by identifying the major revenue sources available and focusing innovations on the enhancement of those sources, it is clear that there are gains to be made from the nurturing of subscribers and advertisers, as well as from the creation of regional networks.

This study forms the first step in a longer-term research project focusing on the effectiveness and impact of business models in the digital contents sector. The development of regional online newspapers in Germany, France and Italy has shown that there is a wide variety of levels of sophistication in the approaches taken, and that cultural and regional perceptions and demands vary widely. In later work we will be investigating these data in greater detail but even this preliminary work has indicated new directions for researchers focusing on e-business model development and evaluation.

\section{References}

1 Zeit, D. (2002) Noch in Dieser Woche, No. 27, pp.11-14.

2 Afuah, A. and Tucci, C.L. (2001) Internet Business Models and Strategies.

3 Bartussek, J. (2001) Vom Newspaper zum Newsfilter, in Andrej Vizjak, Max Ringlstetter, Medienmanagement: Content gewinnbringend nutzen, Trends, Business-Modelle, Erfolgsfaktoren, Wiesbaden, pp.S63-S73.

4 Farhoomand, A. and Lovelock, P (2001) Global E-commerce, TEXT and CASES, Singapore.

5 Niewiarra, M. (2001) Der Rahmen: Content Management in der dritten Generation der Telekommunikation, in Andrej Vizjak, Max Ringlstetter, Medienmanagement: Content gewinnbringend nutzen, Trends, Business-Modelle, Erfolgsfaktoren, Wiesbaden, pp.S45-S59.

6 Rayport, J.F. (1999) The Truth about Internet Business Models, http://www.strategy-business.com/press/article/?art=14631\&pg=0.

7 Weill, P. and Vitale, M.R. (2001) Place to Space, Migrating to eBusiness Models.

8 Wirtz, B.W. (2001) Medien- und Internetmanagement, Wiesbaden.

9 Jarvenpaa, S. (1991) 'Panning for gold in information systems research: 'second-hand' data', in Nissen, H-E., Klien, H.K. and Hirschheim, R. (Eds.): Information Systems Research: Contemporary Approaches and Emergent Traditions, North-Holland, pp.63-80.

10 Neuman, W.L. (2000) Social Research Methods: Qualitative and Quantitative Approaches, 4th ed., Allyn and Bacon, Boston.

11 Byrne, C. (2002) FT.com says 17,000 now paying, in: http://media.guardian.co.uk/newmedia/ story/0,7496,765179,00.html.

12 eMarket (2002) Infonline startet ab September, in: http://www.emar.de/emar/news/archiv/ 1/a10803/index.html. 